\title{
QUEEN'S
UNIVERSITY
BELFAST
}

\section{Extending the functionality of the slurry ferrihydrite-DGT method: Performance evaluation for the measurement of vanadate, arsenate, antimonate and molybdate in water}

Zhang , S., Williams, P. N., Zhou, C-Y., Ma, L. Q., \& Luo, J. (2017). Extending the functionality of the slurry ferrihydrite-DGT method: Performance evaluation for the measurement of vanadate, arsenate, antimonate and molybdate in water. Chemosphere, 184, 812-819. https://doi.org/10.1016/j.chemosphere.2017.06.062

Published in:

Chemosphere

Document Version:

Peer reviewed version

Queen's University Belfast - Research Portal:

Link to publication record in Queen's University Belfast Research Portal

\author{
Publisher rights \\ Copyright 2017 Elsevier. \\ This manuscript is distributed under a Creative Commons Attribution-NonCommercial-NoDerivs License \\ (https://creativecommons.org/licenses/by-nc-nd/4.0/), which permits distribution and reproduction for non-commercial purposes, provided the \\ author and source are cited.
}

\section{General rights}

Copyright for the publications made accessible via the Queen's University Belfast Research Portal is retained by the author(s) and / or other copyright owners and it is a condition of accessing these publications that users recognise and abide by the legal requirements associated with these rights.

\section{Take down policy}

The Research Portal is Queen's institutional repository that provides access to Queen's research output. Every effort has been made to ensure that content in the Research Portal does not infringe any person's rights, or applicable UK laws. If you discover content in the Research Portal that you believe breaches copyright or violates any law, please contact openaccess@qub.ac.uk. 
$5{ }^{1}$ State Key Laboratory of Pollution Control and Resource Reuse, School of the

6 Environment, Nanjing University, Nanjing, Jiangsu 210023, P. R. China

$7 \quad 2$ Institute for Global Food Security, School of Biological Sciences, Queen’s

8 University Belfast, Belfast BT9 7BL, United Kingdom

$9{ }^{3}$ Soil and Water Science Department, University of Florida, Gainesville, Florida 10 32611, United States

11

12

13

14

15

16

17

\section{arsenate, antimonate and molybdate in water}

* Corresponding authors, 0086-25-89680632, esluojun@nju.edu.cn 


\section{Abstract}

The monitoring of oxyanions in waters, presents significant challenges due to their relatively low concentrations, and a characteristically changeable/unstable/reactive geochemistry with high spatial and temporal turnover. This results in a very heterogeneous pattern of mobility and bioavailability, which is difficult to capture reliably and in a cost effective manner. The diffusive gradients in thin-films (DGT) technique is a popular analytical tool for testing water quality, primarily because it provides a time-integrated measurement. However, to date, the most widely used DGT configuration for oxyanion sampling, the slurry ferrihydrite binding layer (SF-DGT) has only been fully characterised for phosphate. Confirmatory testing of the functional range of ionic strengths, $\mathrm{pH}$, deployment times and ionic competition effects, that the SF-DGT's operates within over has not been carried out, but is addressed in this study for $\mathrm{V}^{\mathrm{V}}, \mathrm{As}^{\mathrm{V}}, \mathrm{Sb}^{\mathrm{V}}$, and $\mathrm{Mo}^{\mathrm{VI}}$. In this study $\mathrm{SF}-\mathrm{DGT} \mathrm{Sb}^{\mathrm{V}}$ measurements functioned over the largest range of conditions (ionic strength, $0.1-500$ mM; pH 3.86 - 9.90), while ionic strengths above 100 and $500 \mathrm{mM}$ were found to be problematic for $\mathrm{As}^{\mathrm{V}}$ and $\mathrm{Mo}^{\mathrm{VI}}$, respectively. Low $\mathrm{pH}$ (below 4) caused inferences with $\mathrm{V}^{\mathrm{V}}$, conversely $\mathrm{As}^{\mathrm{V}}$ and $\mathrm{Mo}^{\mathrm{VI}}$ determination faltered/deviated from predicted responses in $\mathrm{pH}$ conditions of $\sim 9$. SF-DGT measurements adequately predicted up to weeklong averaged in situ metal oxyanion concentrations in a freshwater river. This study concludes that the SF-DGT configuration is highly suitable for pollution monitoring applications in freshwater systems for key oxyanion species. 


\section{Introduction}

Oxyanions of vanadium(V), arsenic (As), and antimony (Sb) are of significant environmental interest, causing numerous deleterious environmental and/or human health effects. Metal/alloy producers consume around $85 \%$ of globally traded V (Moskalyk and Alfantazi, 2003), with an increasing demand/use for V being driven by the voracious growth in iron/steel during the past half-a-century (Yellishetty et al., 2010). The damage to biota inflicted by V generally increases with species valiancy, with inhibition of numerous enzymatic systems; such as ATPases, protein kinases, ribonucleases, and phosphatases, the primary modes of toxicity action (Mukherjee et al., 2004).

Concern relating to As exposure remains high, due to its potency as a group 1 human carcinogen (Straif et al., 2009) coupled with its wide spread prevalence in the environment (Qin et al., 2009). Whereas, the rapid increase in industrial demand for Sb, in alloys, flame retardants and semi-conductors especially, means it's environmental 'footprint' is also escalating fast (Filella and Williams, 2012; Okkenhaug et al., 2012). Antimony is highly toxic, and when ingested in small doses can cause headaches, dizziness and depression. Long-term exposure damages both the liver and kidney (He and Wan, 2004). Molybdenum (Mo) although an essential mineral nutrient for both plants and animals in trace amounts (Pyrzynska, 2007), is emerging as a water quality issue in regions where there are intensive/extensive copper and sulphide ore extractions (Rodriguez-Iruretagoiena et al., 2016). Other 
new/important sources of Mo pollution, include waste discharges from the manufacture of electronics (Pichler et al., 2017), catalyst use (Pichler et al., 2017), and geogenic release resulting from over extraction from domestic water wells (Pichler and Mozaffari, 2015).

Although trace element oxyanions can exist as a range of different species, V, As and Sb most commonly occur in aerobic waters in the +5 oxidation state as inorganic ions, with +6 being the prevalent valiancy for Mo. There are a number of oxyanion detection methods, including atomic absorption/fluorescence spectrometry (Liu et al., 2010), inductively coupled plasma mass spectrometry (ICP-MS) (Luo et al., 2010), enzymatic assays (El Khalil et al., 2008), monoclonal antibodies tests (Zhu et al., 2007) and biosensor platforms (Gani et al., 2010). Even though these methods are sensitive and have a good detection limit, their potential use for in situ environmental monitoring has perhaps only been partially realized. This is not a direct criticism of these measurement systems per se, rather a reflection of the sampling collection procedures, which tend to be either field or active sampling based.

The DGT technique has a number of advantages compared with traditional grab sampling approaches, and these benefits are summarized in-depth in a recent review (Davison, 2016). However, DGT's key merits are to capture the true solution component of freshwater systems, including in this definition, readily labile complexed metal species, which are often not accounted for by other measurement 
techniques, while, providing a means to obtain multi-dimensional (temporal/spatial) data in a cost effective manner with minimal disturbance to the sampling environment (Arditsoglou and Voutsa, 2008).

Ferrihydrite, an amorphous iron oxide mineral phase, has been used extensively as a DGT binding agent for the measurement of oxyanions, and can be prepared in one of two ways: i) slurry ferrihydrite (SF) binding phase is added to a polyacrylamide hydrogel during the casting procedure, ii) precipitated ferrihydrite (PF) binding phase is deposited in solid form from solution within a pre-cast/formed polyacrylamide gel. The main advantage of the ferrihydrite SF compared with the PF variant, is the longer sampler storage time, with the latter recommend for use within 38 days of production (Luo et al., 2010). PF-DGT has been used for the measurement of $\mathrm{V}^{\mathrm{V}}, \mathrm{As}^{\mathrm{V}}, \mathrm{Sb}^{\mathrm{V}}, \mathrm{Se}^{\mathrm{VI}}$ and dissolved reactive phosphorus (Zhang et al., 1998; Luo et al., 2010). Another DGT technique using a titanium dioxide-based adsorbent (Metsorb-DGT) has been used to measure a variety of anionic species: $\mathrm{V}^{\mathrm{V}}, \mathrm{As}^{\mathrm{V}}, \mathrm{Se}^{\mathrm{IV}}, \mathrm{Mo}^{\mathrm{VI}}, \mathrm{Sb}^{\mathrm{V}}, \mathrm{P}^{\mathrm{V}}$ and $\mathrm{W}^{\mathrm{VI}}$ (Bennett et al., 2010; Panther et al., 2010; Panther et al., 2013). Zirconium oxide (Zr-oxide DGT) as a binding agent in DGT has also been studied for quantification of $\mathrm{P}^{\mathrm{V}}, \mathrm{V}^{\mathrm{V}}, \mathrm{As}^{\mathrm{V}}, \mathrm{Se}^{\mathrm{VI}}, \mathrm{Mo}^{\mathrm{VI}}$ and $\mathrm{Sb}^{\mathrm{V}}$ (Guan et al., 2015). While Amberlite resins have been used as binders in DGT for $\mathrm{As}^{\mathrm{V}}$ (Rolisola et al., 2014) and $\mathrm{V}^{\mathrm{V}}$ (Luko et al., 2017). Although SF gels based DGT devices (SF-DGT) have been tested for phosphate in water, the performance characteristics of SF-DGT responding to changing environmental conditions and its field application have not been systematically tested 
for $\mathrm{V}^{\mathrm{V}}, \mathrm{As}^{\mathrm{V}}, \mathrm{Sb}^{\mathrm{V}}$ and $\mathrm{Mo}^{\mathrm{VI}}$.

The overall aim of this study were as follows: to characterize the elution efficiency of $\mathrm{V}^{\mathrm{V}}, \mathrm{As}^{\mathrm{V}}, \mathrm{Sb}^{\mathrm{V}}$ and $\mathrm{Mo}^{\mathrm{VI}}$ from the SF binding gels; to ascertain the performance responses of the SF gels-DGT to different ionic strengths, $\mathrm{pH}$, deployment times and ionic competition effects; and to determine detect limit of method. The performance characteristics of the DGT devices containing SF in natural water were tested in field the as well.

\section{Materials and Methods}

\subsection{Preparation of solutions and DGT}

Chemicals used in this study were of analytical reagent grade. $\mathrm{V}^{\mathrm{V}}, \mathrm{As}^{\mathrm{V}}, \mathrm{Sb}^{\mathrm{V}}$ and $\mathrm{Mo}^{\mathrm{VI}}$ stock solutions were prepared at $1000 \mathrm{mg} \mathrm{L}^{-1}$ using sodium orthovanadate, sodium arsenate, sodium antimonate and sodium molybdate. All oxyanion solutions were diluted from the stock solutions. To avoid possible oxidation changes, solutions were used within 1 day of preparation. All solutions used in this experiment were prepared using high purity water (18.2 M $\Omega \mathrm{cm}$, Milli-Q, Millipore, USA).

\footnotetext{
A standard DGT piston device comprises a plastic base, a binding gel layer, a diffusive gel layer, a 0.14-mm-thick hydrophilic polyethersulfone membrane with $0.45 \mu \mathrm{m}$ pore size, and a plastic cap with a circular $2.51 \mathrm{~cm}^{2}$ window (Zhang et al., 1998).
} 
Preparation of slurry ferrihydrite gels. Firstly, SF was prepared by titrating $0.1 \mathrm{M}$

$\mathrm{Fe}\left(\mathrm{NO}_{3}\right)_{3}$ with $1 \mathrm{M} \mathrm{NaOH}$. To avoid an excessively high $\mathrm{OH}^{-}$concentration, which affects the binding ability of the ferrihydrite, the $\mathrm{Fe}^{3+}$ solution was stirred vigorously to make sure the $\mathrm{pH}$ was $<7$ (Zhang et al., 1998). The dark brown-red ferrihydrite was obtained when a pH 6-7 was reached. The obtained SF was washed 3 times with high 
151

152

\subsection{DGT concentration calculation}

In this study, the mass of $\mathrm{V}^{\mathrm{V}}, \mathrm{As}^{\mathrm{V}}, \mathrm{Sb}^{\mathrm{V}}$ or $\mathrm{Mo}^{\mathrm{VI}}$ in the binding gel was calculated using Eq. 1 (Zhang and Davison, 1995):

$$
M=C_{\mathrm{e}} \times\left(V_{\mathrm{gel}}+V_{\mathrm{HNO}_{3}}\right) / f_{\mathrm{e}}
$$

Where $C_{\mathrm{e}}$ is the concentrations of $\mathrm{V}^{\mathrm{V}}, \mathrm{As}^{\mathrm{V}}, \mathrm{Sb}^{\mathrm{V}}$ or $\mathrm{Mo}^{\mathrm{VI}}$ in elution samples, $V_{\text {gel }}$ is the volume, which is $0.18 \mathrm{~mL}$, of the binding gel, $V_{\mathrm{HNO}}$ is the volume of added $\mathrm{HNO}_{3}$ solution, and $f_{\mathrm{e}}$ is the elution efficiency of the target element from the binding gel.

Concentration measured by DGT, C CGT, was calculated by Eq. 2 (Zhang and Davison, 1995):

$$
C_{\mathrm{DGT}}=\frac{M \Delta g}{D A t}
$$

$M$ is the mass of the target element adsorbed by the binding gel, $\Delta \mathrm{g}$ is the thickness of the diffusive gel, $A$ is the area of the exposure window of the DGT device, $D$ is the diffusion coefficient of the target element and $t$ is the deployment time. Table S1 lists D values used in this study.

\subsection{Kinetics of Binding and Elution Efficiency}

In order to check the adsorption kinetics of SF gels, the gels were loaded with a known amount of $\mathrm{V}^{\mathrm{V}}, \mathrm{As}^{\mathrm{V}}, \mathrm{Sb}^{\mathrm{V}}$ or $\mathrm{Mo}^{\mathrm{VI}}$ by shaking the gels in $10 \mathrm{~mL}$ of $100 \mu \mathrm{g} \mathrm{L}^{-1}$ of $\mathrm{V}^{\mathrm{V}}, \mathrm{As}^{\mathrm{V}}, \mathrm{Sb}^{\mathrm{V}}$ or $\mathrm{Mo}^{\mathrm{VI}}$, with a matrix of $10 \mathrm{mM} \mathrm{NaNO}_{3}$, for various times from 0.5 min to $24 \mathrm{~h}$. Concentrations of these elements in the solutions before and after gel immersion were measured using ICP-MS (PerkinElmer NexION 300X, USA) to 
172 calculate the adsorbed elements. The SF gels loaded with different amounts of $\mathrm{V}^{\mathrm{V}}$, $173 \mathrm{As}^{\mathrm{V}}, \mathrm{Sb}^{\mathrm{V}}$ or $\mathrm{Mo}^{\mathrm{VI}}$ were eluted by using different concentrations (1, 3, 4 or $5 \mathrm{M}$ ) of 174 nitric acid for at least $24 \mathrm{~h}$. The concentrations of $\mathrm{V}^{\mathrm{V}}, \mathrm{As}^{\mathrm{V}}, \mathrm{Sb}^{\mathrm{V}}$ or $\mathrm{Mo}^{\mathrm{VI}}$ in the eluents 175 were quantified measured by ICP-MS, after diluting the samples 100 times with 176 ultrapure water/MQ (Luo et al., 2010). Internal standard (50 $\left.\mu \mathrm{g} \mathrm{L}^{-1}\right)$ was mixed with 177 the samples/standards via online standard addition just prior to measurement. The 178 recovery of In for all samples was between $80-120 \%$, indicating a stable analysis run 179 and minimal impact of matrix interferences on the measurements.

\subsection{Effect of Ionic Strength, $\mathrm{pH}$ and Deployment Time}

To test the effects of ionic strength on the measurement of DGT, triplicate SF-DGT were deployed for $4 \mathrm{~h}$ (measured precisely) in well stirred $2 \mathrm{~L}$ solution ( $\mathrm{pH} 5.85$ ) containing $\mathrm{V}^{\mathrm{V}}, \mathrm{As}^{\mathrm{V}}, \mathrm{Sb}^{\mathrm{V}}$ or $\mathrm{Mo}^{\mathrm{VI}}$ (each at $50 \mu \mathrm{g} \mathrm{L}^{-1}$ ) and a range of $\mathrm{NaNO}_{3}$ concentration $(0,0.1,1,10,100$ and $500 \mathrm{mM})$ at known constant temperatures.

In order to investigate the effects of $\mathrm{pH}$ on the performance of DGT, triplicate SF-DGT were deployed for $4 \mathrm{~h}$ (measured precisely) in $2 \mathrm{~L}$ solution containing 10 mM $\mathrm{NaNO}_{3}$ at different pHs adjusted using $1 \mathrm{M} \mathrm{HNO}_{3}$ and $1 \mathrm{M} \mathrm{NaOH}$ prior to

190 spiking with $\mathrm{V}^{\mathrm{V}}, \mathrm{As}^{\mathrm{V}}, \mathrm{Sb}^{\mathrm{V}}$ or $\mathrm{Mo}^{\mathrm{VI}}$ stock solutions to $50 \mu \mathrm{g} \mathrm{L}^{-1}$. Temperatures were 191 also measured.

193 To evaluate the effect of deployment times on DGT performance characteristics, 
194

195

196

197

198

199

200

201

202

203

204

205

206

207

208

209

210

211

212

213

214

215

triplicate SF-DGT were immersed in $6 \mathrm{~L}$ solution (pH 5.83) containing $30 \mu \mathrm{g} \mathrm{L}^{-1}$ of $\mathrm{V}^{\mathrm{V}}, \mathrm{As}^{\mathrm{V}}, \mathrm{Sb}^{\mathrm{V}}$ or $\mathrm{Mo}^{\mathrm{VI}}$ and $10 \mathrm{mM} \mathrm{NaNO}$ and then retrieved in different times (from 4 to $72 \mathrm{~h}$ ).

2.5. Competition effect with between $\mathrm{V}^{V}, \mathrm{As}^{V}, \mathrm{Sb}^{V}, \mathrm{Mo}^{V I}, \mathrm{PO}_{4}{ }^{3-}$ and $\mathrm{SO}_{4}{ }^{2-}$

Competition effect among these six oxyanions in solutions was studied using solutions with different concentration ratios of these oxyanions. Triplicate SF-DGT were deployed for $4 \mathrm{~h}$ (measured precisely) in well stirred solutions (2 L): (a) $10 \mathrm{mM}$ $\mathrm{NaNO}_{3}$, one of $\mathrm{V}^{\mathrm{V}}, \mathrm{As}^{\mathrm{V}}, \mathrm{Sb}^{\mathrm{V}}$ or $\mathrm{Mo}^{\mathrm{VI}}$ at $10 \mu \mathrm{g} \mathrm{L}^{-1}$ and the other three elements at 100 $\mu \mathrm{g} \mathrm{L}^{-1}$; (b) $10 \mathrm{mM} \mathrm{NaNO}, \mathrm{V}^{\mathrm{V}}, \mathrm{As}^{\mathrm{V}}, \mathrm{Sb}^{\mathrm{V}}$ and $\mathrm{Mo}^{\mathrm{VI}}$ at $10 \mu \mathrm{g} \mathrm{L}^{-1}, \mathrm{PO}_{4}{ }^{3-}$ at $100 \mu \mathrm{g} \mathrm{L}^{-1}$; (c) $\mathrm{V}^{\mathrm{V}}, \mathrm{As}^{\mathrm{V}}, \mathrm{Sb}^{\mathrm{V}}$ and $\mathrm{Mo}^{\mathrm{VI}}$ at $50 \mu \mathrm{g} \mathrm{L}^{-1}, \mathrm{SO}_{4}{ }^{2-}$ at $0.1,1,10$ and $100 \mathrm{mM}$.

\subsection{Field deployment of SF-DGT devices in freshwater river}

To validate the applicability of the SF-DGT in natural water, DGT devices were used to measure $\mathrm{V}^{\mathrm{V}}$, $\mathrm{As}^{\mathrm{V}}, \mathrm{Sb}^{\mathrm{V}}$ or $\mathrm{Mo}^{\mathrm{VI}}$ in the Jiuxiang River, a freshwater river located near Nanjing University, China. The basic parameters of the river water were listed in Table S2. Temperature and $\mathrm{pH}$ measured in Jiuxiang River during testing SF-DGT were shown in Fig. S1. Six DGT devices were assembled as a hexahedral unit, leaving the exposure windows facing outwards (Pan et al., 2015; Zheng et al., 2015), and bound with button thermometers (Maxim Integrated Products, USA) to record temperature of water at intervals of $1 \mathrm{~h}$. The hexahedral unit was immersed in the river water and retrieved after 5 days. Water samples were collected at 10 a.m. and 5 
p.m. every day to monitor the concentrations of $\mathrm{V}^{\mathrm{V}}, \mathrm{As}^{\mathrm{V}}, \mathrm{Sb}^{\mathrm{V}}$ or $\mathrm{Mo}^{\mathrm{VI}}$. The water samples were taken to the laboratory within 10 min after sampling, filtered through 0.45-mm pore size membrane and stored at $4{ }^{\circ} \mathrm{C}$ for further analysis.

\section{Results and discussion}

\subsection{DGT Blanks and Detection Limits}

Blank concentrations were evaluated by determining the mass of oxyanions existing in SF gels in DGT devices which were left assembled for the same time as the deployed DGT devices. Blank concentrations of DGT devices were calculated from the measured masses of analytes on the SF gel assuming a deployment time of $24 \mathrm{~h}$ at $25{ }^{\circ} \mathrm{C}$ with a $0.89 \mathrm{~mm}$ thick diffusive layer including a $0.14 \mathrm{~mm}$ filter membrane. As for development of a new analysis method, method detection limits (MDL), calculated as three times the standard deviation of the blank concentrations, is necessary. Table 1 lists the calculated blank concentrations and MDL of SF-DGT $(n=7)$. These data were lower than those reported by Luo et al. (2010), probably due to the higher quality of the chemicals used in this study, suggesting that high purity of chemicals can decrease the gel blank concentrations and MDLs considerably. Furthermore, these lower MDL and gel blank concentrations indicate that SF-DGT have a greater performance potential than previously thought.

SF-DGT deployments measured by ICP-MS analysis are sufficiently reproducible and free from contamination and analysis interferences to enable high accuracy, high 
precision, and high sensitivity analysis of $\mathrm{V}^{\mathrm{V}}, \mathrm{As}^{\mathrm{V}}, \mathrm{Sb}^{\mathrm{V}}$ or $\mathrm{Mo}^{\mathrm{VI}}$ in natural samples. However, matrix effects can be a problem, particularly, for determination of As by ICP-MS, since the eluent from SF gels can be highly enriched in dissolved $\mathrm{Fe}^{2+}$. However, in this study, a 100 times dilution of the eluent prior to measurement, overcame any potential measurement interferences for As or other elements. The total amount of ferrihydrite per resin gel disc is about $500 \mathrm{mg}$, based on ferrihydrite being completely dissolved during elution, the maximum concentration of $\mathrm{Fe}^{2+}$ in the sample after dilution would be $5 \mathrm{mg} \mathrm{L}^{-1}$, which is a loading that ICP-MS systems can accommodate, as long as isotopes of iron are not measured directly as this could impact on the detector lifetime.

\subsection{Elution Efficiency and Kinetics of Binding}

How to efficiently elute these oxyanions from SF gels is a prerequisite of accurate DGT measurement. Strong acids can digest and destroy the structure of the gels for complete release of elements from the binding layer. Previous studies showed that $0.25 \mathrm{M} \mathrm{H}_{2} \mathrm{SO}_{4}$ were used to elute SF gels for $\mathrm{P}^{\mathrm{V}}$ and concentrated $\mathrm{HCl}$ (Panther et al., 2008a, b) or $\mathrm{HNO}_{3}$ (Fitz et al., 2003; Sogn et al., 2008) for $\mathrm{As}^{\mathrm{V}}$ and $\mathrm{Se}^{\mathrm{VI}}$. However, higher concentrations of acid used means greater dilutions steps are required for ICP-MS analysis, hence decreasing concentrations of target elements in samples and increasing the uncertainty of analysis, especially at lower concentrations. $1 \mathrm{M} \mathrm{HNO}_{3}$ is commonly used to elute elements from several binding gels, including PF gels (Luo et al., 2010), and chelex gels (Scally et al., 2006). Here, $1 \mathrm{M} \mathrm{HNO}_{3}$ was firstly chosen 
to elute $\mathrm{V}^{\mathrm{V}}, \mathrm{As}^{\mathrm{V}}, \mathrm{Sb}^{\mathrm{V}}$ and $\mathrm{Mo}^{\mathrm{VI}}$ from SF gels. However, the elution efficiency of $\mathrm{As}^{\mathrm{V}}$ and $\mathrm{Mo}^{\mathrm{VI}}$ were relatively low (Table 2). Then higher concentrations (3, 4 and $5 \mathrm{M}$ ) of nitric acid were trialed. The findings were that, the elution efficiencies of $\mathrm{V}^{\mathrm{V}}, \mathrm{As}^{\mathrm{V}}$, $\mathrm{Sb}^{\mathrm{V}}$ or $\mathrm{Mo}^{\mathrm{VI}}$ are not significantly different when either 3, 4 or $5 \mathrm{M} \mathrm{HNO}_{3}$ is used. The elution efficiencies $\left(f_{\mathrm{e}}\right)$ of $\mathrm{As}^{\mathrm{V}}, \mathrm{Sb}^{\mathrm{V}}$ or $\mathrm{Mo}^{\mathrm{VI}}$ were stable at $\sim 0.9$ while $\mathrm{V}$ was slightly lower at around 0.81 . In this study, $4 \mathrm{M} \mathrm{HNO}_{3}$ was used for elution of all elements from the SF gels.

SF gels immersed into solutions containing $100 \mu \mathrm{g} \mathrm{L}^{-1}$ of $\mathrm{V}^{\mathrm{V}}, \mathrm{As}^{\mathrm{V}}, \mathrm{Sb}^{\mathrm{V}}$ or $\mathrm{Mo}^{\mathrm{VI}}$ accumulated about $70 \%$ of the total amount of the dissolved elements in the first 10 min (Fig. 1.). The mass accumulated after 60 min was similar to that measured at $24 \mathrm{~h}$. Similar time dependency trends were observed in PF gels and other binding layers (Luo et al., 2010; Zhou et al., 2016). In the first 10 min, the relationship between the accumulated mass of the element and time is almost linear. It provides direct evidence that binding of the target element to the SF gels within DGT is sufficiently fast to ensure that its concentration at the interface of the diffusive gel close to the binding gel is effectively zero (Luo et al., 2010). For instance, the measured mass of $\mathrm{V}^{\mathrm{V}}$ accumulated within 10 min corresponds to a flux of $32.03 \mathrm{ng} \mathrm{cm}^{-2} \mathrm{~min}^{-1}$, which is a far greater flux than is measured through the diffusion layer of a DGT device deployed in solution containing $1 \mathrm{mg} \mathrm{L}^{-1} \mathrm{~V}^{\mathrm{V}}\left(5.41 \mathrm{ng} \mathrm{cm}^{-2} \mathrm{~min}^{-1}\right)$.

\subsection{Effect of Ionic Strength and pH on DGT performance}


The effects of different ionic strength on uptake of $\mathrm{V}^{\mathrm{V}}, \mathrm{As}^{\mathrm{V}}, \mathrm{Sb}^{\mathrm{V}}$ and $\mathrm{Mo}^{\mathrm{VI}}$ by SF-DGT are shown in Fig. 2. In the solution containing 0.1, 1, 10, and $100 \mathrm{mM} \mathrm{HNO}_{3}$, the ratios, $R$, of DGT measured to solution concentrations of $\mathrm{V}^{\mathrm{V}}, \mathrm{As}^{\mathrm{V}}, \mathrm{Sb}^{\mathrm{V}}$ or $\mathrm{Mo}^{\mathrm{VI}}$ were in an acceptable range except for $\mathrm{As}^{\mathrm{V}}$ at $100 \mathrm{mM}$. However, all the $R$ values were significantly lower than 1 for deployment in solutions without added $\mathrm{NaNO}_{3}$ and $R$ values of $\mathrm{As}^{\mathrm{V}}$ and $\mathrm{Mo}^{\mathrm{VI}}$ declined substantially when the concentration of $\mathrm{NaNO}_{3}$ reached $500 \mathrm{mM}$ (Fig. 2). Since when diffusive gels are very well washed, they have a very small positive charge (Warnken et al., 2005), which in solutions of very low ionic strength gives rise to Donnan portioning at the gel-solution interface (Yezek and van Leeuwen, 2004; Yezek et al., 2008), and there can be a consequent lowering of the effective diffusion coefficient of oxyanion species. Because the ionic strength of seawater is approximate $700 \mathrm{mM}$, the technique is not appropriate for saline water deployments if it is used to measure $\mathrm{As}^{\mathrm{V}}$ and $\mathrm{Mo}^{\mathrm{V}}$. However, since the ionic strength in fresh and most wastewaters is lower than $100 \mathrm{mM}$ (Turner et al., 1981; Glass and Silverstein, 1999), SF-DGT can effectively measure these elements in these water bodies.

For $\mathrm{pH}$ in the range of $4.87-8.01$, the ratio of SF-DGT measured concentration to solution concentration of $\mathrm{V}^{\mathrm{V}}, \mathrm{As}^{\mathrm{V}}, \mathrm{Sb}^{\mathrm{V}}$ or $\mathrm{Mo}^{\mathrm{VI}}$ was within the acceptable ranges (1.0 \pm 0.1 ). But the $R$ value of $\mathrm{V}^{\mathrm{V}}$ at $\mathrm{pH} 3.86$ is low. Even at $\mathrm{pH}$ of 4.87 , the $R$ value of $\mathrm{V}^{\mathrm{V}}$ is inaccurate (Fig. 3). This is likely due to different ionic forms corresponding to different $\mathrm{pH}$ situations. In the Supplementary data (Fig. S3), at $\mathrm{pH}$ lower than 5.5, 
most of $\mathrm{V}^{\mathrm{V}}$ in solution exists as $\mathrm{VO}^{2+}$ with positively charged species dominating while $\mathrm{V}^{\mathrm{V}}$ is existed as $\mathrm{HVO}_{4}{ }^{2-}$ when $\mathrm{pH}$ is higher than 5.5. Because the SF gel surface is positively charged below $\mathrm{pH}$ 5.5, the binding of positively charged species can be expected to be weak. At higher $\mathrm{pH}$, the $\mathrm{C}_{\mathrm{DGT}} / \mathrm{C}_{\text {soln }}$ of $\mathrm{As}^{\mathrm{V}}, \mathrm{Mo}^{\mathrm{VI}}$ and $\mathrm{V}^{\mathrm{V}}, \mathrm{Sb}^{\mathrm{V}}$ were greatly reduced when $\mathrm{pH}$ was increased to 8.97 and 9.90 respectively. The lower zero point of charge (zpc) of ferrihydrite of 8 compared to 9 for goethite is due to proton binding mainly occurring at singly coordinated surface groups (Hiemstra and Van Riemsdijk, 2009). The specific inner-sphere binding of arsenate can lower the zpc (Goldberg and Johnston, 2001). However, the change in zpc within the binding gel of DGT is likely to be slight, as the concentrations of the anion are lowered by binding and constrain diffusional supply. When the charge on the surface of SF gels becomes negative, there is likely to be much weaker adsorption of oxyanions. In conclusion, the excellent $\mathrm{R}$ values recorded for a wide $\mathrm{pH}$ range (4.87-8.01) shows a good application prospect of SF-DGT in acidic to alkaline waters.

\subsection{Effect of Deployment Time on DGT performance}

The measured mass of $\mathrm{V}^{\mathrm{V}}, \mathrm{As}^{\mathrm{V}}, \mathrm{Sb}^{\mathrm{V}}$ or $\mathrm{Mo}^{\mathrm{VI}}$ accumulated by SF-DGT increased linearly with deployment time over $72 \mathrm{~h}$ and agreed well with the theoretical values calculated from the known solution concentrations $\left(30 \mu \mathrm{g} \mathrm{L}^{-1}\right.$ of $\mathrm{V}^{\mathrm{V}}, \mathrm{As}^{\mathrm{V}}, \mathrm{Sb}^{\mathrm{V}}$ or $\mathrm{Mo}^{\mathrm{VI}}$ and $10 \mathrm{mM} \mathrm{NaNO}_{3}$ ) (Fig. S2). A previous study reported that the rate of mass accumulation of $\mathrm{As}^{\mathrm{V}}$ by SF-DGT decreased after $24 \mathrm{~h}$, indicating a possible deterioration of sorption of the SF gels during deployment (Sogn et al., 2008). 
However, there was no such effect appearing in SF-DGT investigated in this study (Fig. S2) inferred performance characteristics of SF-DGT did not change within $72 \mathrm{~h}$.

\subsection{Competition Effects}

SF-DGT was immersed in a series of synthetic solutions with different concentrations of oxyanions to test possible competition effects between these oxyanions. Table 3 showed that $\mathrm{R}$ values obtained at different concentration ratios of $\mathrm{V}^{\mathrm{V}}, \mathrm{As}^{\mathrm{V}}, \mathrm{Sb}^{\mathrm{V}}, \mathrm{Mo}^{\mathrm{VI}}$ and $\mathrm{PO}_{4}^{3-}$ were in an acceptable range (0.9-1.1), indicating that no significant interference from these oxyanions existed and possible competition effects between these oxyanions make no difference to SF-DGT. When $\mathrm{SO}_{4}{ }^{2-}$ were at $0-10 \mathrm{mM}$, the ratio of SF-DGT measured concentration to solution concentration of $\mathrm{V}^{\mathrm{V}}, \mathrm{As}^{\mathrm{V}}, \mathrm{Sb}^{\mathrm{V}}$ or $\mathrm{Mo}^{\mathrm{VI}}$ was within the acceptable ranges $(1.0 \pm 0.1)$ (Fig. 4). However, when the concentration of $\mathrm{SO}_{4}{ }^{2-}$ increased to $100 \mathrm{mM}$, the $\mathrm{R}$ values of $\mathrm{Mo}^{\mathrm{VI}}$ and $\mathrm{Sb}^{\mathrm{V}}$ were slightly lower than 0.9 . As usual, in the groundwater, the concentration of $\mathrm{SO}_{4}{ }^{2-}$ was between 0.005 and $5 \mathrm{mM}$ (Morales et al., 2000). The competition of $\mathrm{SO}_{4}{ }^{2-}$ is not a problem if SF-DGT is used in the groundwater.

\subsection{The application of SF-DGT devices in freshwater river}

Test experiments of SF-DGT under different conditions in the laboratory showed that the SF-DGT is likely to be a reliable tool for measuring $\mathrm{V}^{\mathrm{V}}, \mathrm{As}^{\mathrm{V}}, \mathrm{Sb}^{\mathrm{V}}$ and $\mathrm{Mo}^{\mathrm{VI}}$ in waters. To prove this proposition working in the field, concentrations of these four elements were measured using SF-DGT devices deployed in the Jiuxiang River and 
compared with those determined using an active sampling method. The average concentrations of four elements in the river acquired by active sampling at 10 am and $5 \mathrm{pm}$ from day 1 to 5 were $2.37 \pm 0.02,3.55 \pm 0.04,3.11 \pm 0.07$, and $0.68 \pm 0.02 \mu \mathrm{g}$ $\mathrm{L}^{-1}$ for $\mathrm{V}$, As, Sb and Mo, respectively, which were comparable to those found in the lagoon of Venice (the concentrations of V, As, Sb and Mo were 0.69-3.21, 1.42-2.27, 0.14-0.52, and 6.50-10.62 $\mu \mathrm{g} \mathrm{L} \mathrm{L}^{-1}$, respectively) (Turetta et al., 2005) and the Sacramento River in California (the concentrations of V, As, Sb and Mo and are 9.1, 2.8, 0.26, and 2.6 $\mu \mathrm{g} \mathrm{L}^{-1}$, respectively) (Taylor et al., 2012).

The averaged DGT-measured concentrations of $\mathrm{V}^{\mathrm{V}}, \mathrm{As}^{\mathrm{V}}, \mathrm{Sb}^{\mathrm{V}}$ and $\mathrm{Mo}^{\mathrm{VI}}$ were close to the averaged concentrations measured by active sampling, whose $\mathrm{R}$ values were at 1.00, 0.99, 1.02 and 1.00, respectively. Meanwhile, as shown in Fig. 5, even though the concentrations in water fluctuated slightly with the time, the most of water concentrations (black points) were located between two dotted black lines (representing maximum and minimum DGT measured concentrations). It indicated the range of DGT-measured concentrations were consistent with the concentrations measured by active sampling method. The averaged values provided by DGT could substitute for high frequency grab sampling.

\section{Conclusions}

According to the adsorption kinetics of SF gel, the adsorption rates were high enough to meet the technical requirement of DGT. SF-DGT deployments measured by 
ICP-MS analysis enable high accuracy, high precision, and high sensitivity analysis of $\mathrm{V}^{\mathrm{V}}, \mathrm{As}^{\mathrm{V}}, \mathrm{Sb}^{\mathrm{V}}$ and $\mathrm{Mo}^{\mathrm{VI}}$. For eluent, $4 \mathrm{M} \mathrm{HNO} \mathrm{HN}_{3}$ was found to be optimum, with steady elution efficiency at around 90\%. SF-DGT has an excellent performance in a broad $\mathrm{pH}$ ranges 4.87-8.01, especially at around $\mathrm{pH}$ 6. Furthermore, the SF-DGT detection limits are lower than concentrations of $\mathrm{V}^{\mathrm{V}}, \mathrm{As}^{\mathrm{V}}, \mathrm{Sb}^{\mathrm{V}}$ and $\mathrm{Mo}^{\mathrm{VI}}$ in a number of typical natural water, and in normal conditions competition between the oxyanions is not an issue In general, all the above advantages, combined with a long sampler storage life, make this method convenient for using in a wide range of matrixes, which include rivers, wastewaters, synthetic solutions, sediments and wetland soils.

Trace element, oxyanions are a contamination risk for waters globally. (Ikem et al., 2003; Behbahaninia, 2006; Shikazono et al., 2012; Ficken and Byrne, 2013). So, convenient and easy-to-operate methods for oxyanions detection are especially needed. Meanwhile, for the research community, understanding of the fine-scale mobilization processes occurring at the mineral, soil and sediment-water interfaces are crucially important (Zhang et al., 2016). This extension in functionality of an existing and widely used method presents a new opportunity for improving the way we measure oxyanions in autochthonous and allochthonous systems to improve environmental and human health risk assessment.

\section{Acknowledgements}

This work was funded by the National Natural Science Foundation of China (No. 
21477053), and the NSFC and Newton Fund/Royal Society (No. 21511130063 and R1504GFS).

\section{Appendix A. Supplementary data}

Supplementary data associated with this article can be found, in the online version.

\section{References}

Arditsoglou, A., Voutsa, D., 2008. Passive sampling of selected endocrine disrupting compounds using polar organic chemical integrative samplers. Environ. Pollut. 156, 316-324.

Behbahaninia, A., 2006. Physico-chemical characteristics and pollution levels of heavy metals in Jajrood River, East of Tehran, Iran. Acta Press, Calgary.

Bennett, W.W., Teasdale, P.R., Panther, J.G., Welsh, D.T., Jolley, D.F., 2010. New Diffusive Gradients in a Thin Film Technique for Measuring Inorganic Arsenic and Selenium(IV) Using a Titanium Dioxide Based Adsorbent. Anal. Chem. 82, 7401-7407.

Davison, W., 2016. Diffusive Gradients in Thin-Films for Environmental Measurements. Cambridge University Press.

El Khalil, H., El Hamiani, O., Bitton, G., Ouazzani, N., Boularbah, A., 2008. Heavy metal contamination from mining sites in South Morocco: Monitoring metal content and toxicity of soil runoff and groundwater. Environ. Monit. Assess. 136, 147-160.

Ficken, K.L.G., Byrne, P.G., 2013. Heavy metal pollution negatively correlates with anuran species richness and distribution in south-eastern Australia. Austral Ecol. 38, 523-533.

Filella, M., Williams, P.A., 2012. Antimony interactions with heterogeneous complexants in waters, sediments and soils: A review of binding data for homologous compounds. Chem Erde-Geochem. 72, 49-65.

Fitz, W.J., Wenzel, W.W., Zhang, H., Nurmi, J., Stipek, K., Fischerova, Z., Schweiger, P., Kollensperger, G., Ma, L.Q., Stingeder, G., 2003. Rhizosphere characteristics of the arsenic hyperaccumulator Pteris vittata L. and monitoring of phytoremoval efficiency. Environ. Sci. Technol. 37, 5008-5014.

Gani, A.A., Ashari, M.R., Kuswandi, B., 2010. An Optical Fiber Biosensor for Heavy Metal Ions Based on a Modified Single Sol-Gel Film of Urease and Chlorophenol Red in Flow System. Sens. Lett. 8, 320-327.

Glass, C., Silverstein, J., 1999. Denitrification of high-nitrate, high-salinity wastewater. Water research 33, 223-229.

Goldberg, S., Johnston, C.T., 2001. Mechanisms of arsenic adsorption on amorphous 
oxides evaluated using macroscopic measurements, vibrational spectroscopy, and surface complexation modeling. J. Colloid Interface Sci. 234, 204-216.

Guan, D.X., Williams, P.N., Luo, J., Zheng, J.L., Xu, H.C., Cai, C., Ma, L.N.Q., 2015. Novel Precipitated Zirconia-Based DGT Technique for High-Resolution Imaging of Oxyanions in Waters and Sediments. Environ. Sci. Technol. 49, 3653-3661.

He, M.C., Wan, H.Y., 2004. Distribution, speciation, toxicity and bioavailability of antimony in the environment. Prog. Chem. 16, 131-135.

Hiemstra, T., Van Riemsdijk, W.H., 2009. A surface structural model for ferrihydrite I: Sites related to primary charge, molar mass, and mass density. Geochim. Cosmochim. Acta 73, 4423-4436.

Ikem, A., Egiebor, N.O., Nyavor, K., 2003. Trace elements in water, fish and sediment from Tuskegee Lake, southeastern USA. Water Air Soil Pollut. 149, 51-75.

Liu, L.W., Deng, H., Wu, L., Zheng, C.B., Hou, X.D., 2010. UV-induced carbonyl generation with formic acid for sensitive determination of nickel by atomic fluorescence spectrometry. Talanta 80, 1239-1244.

Luko, K.S., Menegario, A.A., Suarez, C.A., Tafurt-Cardona, M., Pedrobom, J.H., Rolisola, A., Sulato, E.T., Kiang, C.H., 2017. In situ determination of V(V) by diffusive gradients in thin films and inductively coupled plasma mass spectrometry techniques using amberlite IRA-410 resin as a binding layer. Anal. Chim. Acta 950, 32-40.

Luo, J., Zhang, H., Santner, J., Davison, W., 2010. Performance Characteristics of Diffusive Gradients in Thin Films Equipped with a Binding Gel Layer Containing Precipitated Ferrihydrite for Measuring Arsenic(V), Selenium(VI), Vanadium(V), and Antimony(V). Anal. Chem. 82, 8903-8909.

Morales, J.A., de Graterol, L.S., Mesa, J., 2000. Determination of chloride, sulfate and nitrate in groundwater samples by ion chromatography. J. Chromatogr. A 884, 185-190.

Moskalyk, R.R., Alfantazi, A.M., 2003. Processing of vanadium: a review. Miner. Eng. 16, 793-805.

Mukherjee, B., Patra, B., Mahapatra, S., Banerjee, P., Tiwari, A., Chatterjee, M., 2004. Vanadium - an element of atypical biological significance. Toxicol. Lett. 150, 135-143.

Okkenhaug, G., Zhu, Y.G., He, J.W., Li, X., Luo, L., Mulder, J., 2012. Antimony (Sb) and Arsenic (As) in Sb Mining Impacted Paddy Soil from Xikuangshan, China: Differences in Mechanisms Controlling Soil Sequestration and Uptake in Rice. Environ. Sci. Technol. 46, 3155-3162.

Pan, Y., Guan, D.X., Zhao, D., Luo, J., Zhang, H., Davison, W., Ma, L.Q., 2015. Novel Speciation Method Based on Diffusive Gradients in Thin-Films for in Situ Measurement of Cr-VI in Aquatic Systems. Environ. Sci. Technol. 49, 14267-14273.

Panther, J.G., Stewart, R.R., Teasdale, P.R., Bennett, W.W., Welsh, D.T., Zhao, H.J., 2013. Titanium dioxide-based DGT for measuring dissolved As(V), V(V), Sb(V), Mo(VI) and W(VI) in water. Talanta 105, 80-86.

Panther, J.G., Stillwell, K.P., Powell, K.J., Downard, A.J., 2008a. Development and 
application of the diffusive gradients in thin films technique for the measurement of total dissolved inorganic arsenic in waters. Anal. Chim. Acta 622, 133-142.

Panther, J.G., Stillwell, K.P., Powell, K.J., Downard, A.J., 2008b. Perfluorosulfonated Ionomer-Modified Diffusive Gradients in Thin Films: Tool for Inorganic Arsenic Speciation Analysis. Anal. Chem. 80, 9806-9811.

Panther, J.G., Teasdale, P.R., Bennett, W.W., Welsh, D.T., Zhao, H.J., 2010. Titanium Dioxide-Based DGT Technique for In Situ Measurement of Dissolved Reactive Phosphorus in Fresh and Marine Waters. Environ. Sci. Technol. 44, 9419-9424.

Pichler, T., Mozaffari, A., 2015. Distribution and mobility of geogenic molybdenum and arsenic in a limestone aquifer matrix. Applied Geochemistry 63, 623-633.

Pichler, T., Renshaw, C.E., Sultenfuss, J., 2017. Geogenic As and Mo groundwater contamination caused by an abundance of domestic supply wells. Applied Geochemistry 77, 68-79.

Pyrzynska, K., 2007. Determination of molybdenum in environmental samples. Anal Chim Acta 590, 40-48.

Qin, J., Lehr, C.R., Yuan, C.G., Le, X.C., McDermott, T.R., Rosen, B.P., 2009. Biotransformation of arsenic by a Yellowstone thermoacidophilic eukaryotic alga. Proc. Natl. Acad. Sci. U. S. A. 106, 5213-5217.

Rodriguez-Iruretagoiena, A., de Vallejuelo, S.F.O., de Diego, A., de Leao, F.B., de Medeiros, D., Oliveira, M.L.S., Tafarel, S.R., Arana, G., Madariaga, J.M., Silva, L.F.O., 2016. The mobilization of hazardous elements after a tropical storm event in a polluted estuary. Sci. Total Environ. 565, 721-729.

Rolisola, A., Suarez, C.A., Menegario, A.A., Gastmans, D., Kiang, C.H., Colaco, C.D., Garcez, D.L., Santelli, R.E., 2014. Speciation analysis of inorganic arsenic in river water by Amberlite IRA 910 resin immobilized in a polyacrylamide gel as a selective binding agent for $\mathrm{As}(\mathrm{v})$ in diffusive gradient thin film technique. Analyst 139, 4373-4380.

Scally, S., Davison, W., Zhang, H., 2006. Diffusion coefficients of metals and metal complexes in hydrogels used in diffusive gradients in thin films. Anal. Chim. Acta 558, 222-229.

Shikazono, N., Tatewaki, K., Mohiuddin, K.M., Nakano, T., Zakir, H.M., 2012. Sources, spatial variation, and speciation of heavy metals in sediments of the Tamagawa River in Central Japan. Environ. Geochem. Health 34, 13-26.

Sogn, T.A., Eich-Greatorex, S., Royset, O., Ogaard, A.F., Almas, A.R., 2008. Use of diffusive gradients in thin films to predict potentially bioavailable selenium in soil. Commun. Soil Sci. Plant Anal. 39, 587-602.

Stockdale, A., Davison, W., Zhang, H., 2008. High-resolution two-dimensional quantitative analysis of phosphorus, vanadium and arsenic, and qualitative analysis of sulfide, in a freshwater sediment. Environ. Chem. 5, 143-149.

Straif, K., Benbrahim-Tallaa, L., Baan, R., Grosse, Y., Secretan, B., El Ghissassi, F., Bouvard, V., Guha, N., Freeman, C., Galichet, L., Cogliano, V., Workin, W.H.O.I.A.R.C.M., 2009. A review of human carcinogens-Part C: metals, arsenic, dusts, and fibres. Lancet Oncol. 10, 453-454.

Taylor, H.E., Antweiler, R.C., Roth, D.A., Alpers, C.N., Dileanis, P., 2012. Selected 
trace elements in the Sacramento River, California: occurrence and distribution. Archives of environmental contamination and toxicology 62, 557-569.

Turetta, C., Capodaglio, G., Cairns, W., Rabar, S., Cescon, P., 2005. Benthic fluxes of trace metals in the lagoon of Venice. Microchemical Journal 79, 149-158.

Turner, D.R., Whitfield, M., Dickson, A.G., 1981. THE EQUILIBRIUM SPECIATION OF DISSOLVED COMPONENTS IN FRESH-WATER AND SEAWATER AT 25-DEGREES-C AND 1 ATM PRESSURE. Geochim. Cosmochim. Acta 45, 855-881.

Warnken, K.W., Zhang, H., Davison, W., 2004. Performance characteristics of suspended particulate reagent-iminodiacetate as a binding agent for diffusive gradients in thin films. Anal. Chim. Acta 508, 41-51.

Warnken, K.W., Zhang, H., Davison, W., 2005. Trace metal measurements in low ionic strength synthetic solutions by diffusive gradients in thin films. Anal. Chem. 77, 5440-5446.

Yellishetty, M., Ranjith, P.G., Tharumarajah, A., 2010. Iron ore and steel production trends and material flows in the world: Is this really sustainable? Resour. Conserv. Recycl. 54, 1084-1094.

Yezek, L.P., Van der Veeken, P.L.R., Van Leeuwen, H.P., 2008. Donnan Effects in Metal Speciation Analysis by DET/DGT. Environ. Sci. Technol. 42, 9250-9254.

Yezek, L.P., van Leeuwen, H.P., 2004. An electrokinetic characterization of low charge density cross-linked polyacrylamide gels. J. Colloid Interface Sci. 278, 243-250.

Zhang, H., Davison, W., 1995. PERFORMANCE-CHARACTERISTICS OF DIFFUSION GRADIENTS IN THIN-FILMS FOR THE IN-SITU MEASUREMENT OF TRACE-METALS IN AQUEOUS-SOLUTION. Anal. Chem. 67, 3391-3400.

Zhang, H., Davison, W., Gadi, R., Kobayashi, T., 1998. In situ measurement of dissolved phosphorus in natural waters using DGT. Anal. Chim. Acta 370, 29-38.

Zhang, S.-Y., Williams, P.N., Luo, J., Zhu, Y.-G., 2016. Microbial mediated arsenic biotransformation in wetlands. Frontiers of Environmental Science \& Engineering 11.

Zheng, J.L., Guan, D.X., Luo, J., Zhang, H., Davison, W., Cui, X.Y., Wang, L.H., Ma, L.N.Q., 2015. Activated Charcoal Based Diffusive Gradients in Thin Films for in Situ Monitoring of Bisphenols in Waters. Anal. Chem. 87, 801-807.

Zhou, C.Y., Guan, D.X., Williams, P.N., Luo, J., Ma, L.Q., 2016. Novel DGT method with tri-metal oxide adsorbent for in situ spatiotemporal flux measurement of fluoride in waters and sediments. Water research 99, 200-208.

Zhu, X.X., Xu, L., Lou, Y., Yu, H.N., Li, X., Blake, D.A., Liu, F.Q., 2007. Preparation of specific monoclonal antibodies (MAbs) against heavy metals: MAbs that recognize chelated cadmium ions. J. Agric. Food Chem. 55, 7648-7653. 
562 Calculated Blanks, Method Detection Limits (MDL=36blank) and Instrumental

563 Detection Limits for $\mathrm{V}^{\mathrm{V}}, \mathrm{As}^{\mathrm{V}}, \mathrm{Sb}^{\mathrm{V}}$ and $\mathrm{Mo}^{\mathrm{VI}}$ for SF-DGT.

564

\begin{tabular}{cccc}
\hline & Gel blank $\left(\mu \mathrm{g} \mathrm{L}^{-1}\right)$ & MDL $\left(\mu \mathrm{g} \mathrm{L}^{-1}\right)$ & IDL $\left(\mu \mathrm{g} \mathrm{L}^{-1}\right)$ \\
\hline V & $0.014 \pm 0.003$ & 0.009 & 0.0005 \\
As & $0.016 \pm 0.003$ & 0.009 & 0.0006 \\
Sb & $0.038 \pm 0.012$ & 0.036 & 0.0009 \\
Mo & $0.155 \pm 0.004$ & 0.012 & 0.001 \\
\hline
\end{tabular}

565

566 
568 Elution efficiencies of $\mathrm{V}^{\mathrm{V}}, \mathrm{As}^{\mathrm{V}}, \mathrm{Sb}^{\mathrm{V}}$ and $\mathrm{Mo}^{\mathrm{VI}}$ from $\mathrm{SF}$ gels using $1 \mathrm{~mL}$ of different 569 concentrations $(1,3,4$, or $5 \mathrm{M})$ of $\mathrm{HNO}_{3}$. Values were means \pm standard errors of 570 three replicates.

571

\begin{tabular}{ccccc}
\hline & $1 \mathrm{M} \mathrm{HNO}_{3}$ & $3 \mathrm{M} \mathrm{HNO}_{3}$ & $4 \mathrm{M} \mathrm{HNO}_{3}$ & $5 \mathrm{M} \mathrm{HNO}_{3}$ \\
\hline $\mathrm{V}$ & $0.81 \pm 0.01$ & $0.82 \pm 0.05$ & $0.81 \pm 0.04$ & $0.80 \pm 0.04$ \\
$\mathrm{As}$ & $0.50 \pm 0.03$ & $0.89 \pm 0.02$ & $0.89 \pm 0.02$ & $0.89 \pm 0.01$ \\
$\mathrm{Sb}$ & $0.80 \pm 0.02$ & $0.91 \pm 0.05$ & $0.91 \pm 0.04$ & $0.91 \pm 0.05$ \\
$\mathrm{Mo}$ & $0.56 \pm 0.01$ & $0.87 \pm 0.03$ & $0.90 \pm 0.03$ & $0.92 \pm 0.02$ \\
\hline
\end{tabular}

572

573 
574 Table 3. $C_{\mathrm{DGT}} / C_{\text {soln }}$ of $\mathrm{V}^{\mathrm{V}}, \mathrm{As}^{\mathrm{V}}, \mathrm{Sb}^{\mathrm{V}}$ and $\mathrm{Mo}^{\mathrm{VI}}$ measured by SF-DGT deployed in 575 solutions containing $10 \mathrm{mM} \mathrm{NaNO}_{3}$, one of $\mathrm{V}^{\mathrm{V}}, \mathrm{As}^{\mathrm{V}}, \mathrm{Sb}^{\mathrm{V}}$ or $\mathrm{Mo}^{\mathrm{VI}}$ at $10 \mu \mathrm{g} \mathrm{L}^{-1}$ and the 576 other three elements at $100 \mu \mathrm{g} \mathrm{L}^{-1}$ or $\mathrm{V}^{\mathrm{V}}, \mathrm{As}^{\mathrm{V}}, \mathrm{Sb}^{\mathrm{V}}$ or $\mathrm{Mo}^{\mathrm{VI}}$ at $10 \mu \mathrm{g} \mathrm{L}^{-1}$ and $\mathrm{PO}_{4}{ }^{3-}$ at $577 \quad 100 \mu \mathrm{g} \mathrm{L}^{-1}$.

578

\begin{tabular}{ccccc}
\hline Solution & $\mathrm{V}$ & As & Mo & Sb \\
\hline 1 & $0.90 \pm 0.01$ & $1.04 \pm 0.02$ & $1.01 \pm 0.03$ & $1.00 \pm 0.02$ \\
2 & $0.95 \pm 0.04$ & $0.95 \pm 0.02$ & $0.99 \pm 0.05$ & $1.02 \pm 0.05$ \\
3 & $0.99 \pm 0.08$ & $0.93 \pm 0.08$ & $0.92 \pm 0.01$ & $1.03 \pm 0.09$ \\
4 & $1.04 \pm 0.02$ & $0.92 \pm 0.06$ & $0.97 \pm 0.06$ & $0.95 \pm 0.01$ \\
5 & $0.96 \pm 0.07$ & $0.96 \pm 0.02$ & $0.98 \pm 0.03$ & $1.05 \pm 0.08$
\end{tabular}

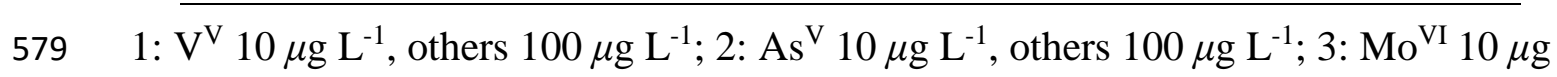

$580 \mathrm{~L}^{-1}$, others $100 \mu \mathrm{g} \mathrm{L}^{-1} ; 4: \mathrm{Sb}^{\mathrm{V}} 10 \mu \mathrm{g} \mathrm{L}^{-1}$, others $100 \mu \mathrm{g} \mathrm{L}^{-1} ; 5: \mathrm{V}^{\mathrm{V}}, \mathrm{As}^{\mathrm{V}}, \mathrm{Sb}^{\mathrm{V}}$ or Mo ${ }^{\mathrm{VI}} 10$ $581 \mu \mathrm{g} \mathrm{L}^{-1}, \mathrm{PO}_{4}{ }^{3-} 100 \mu \mathrm{g} \mathrm{L}^{-1}$.

582 

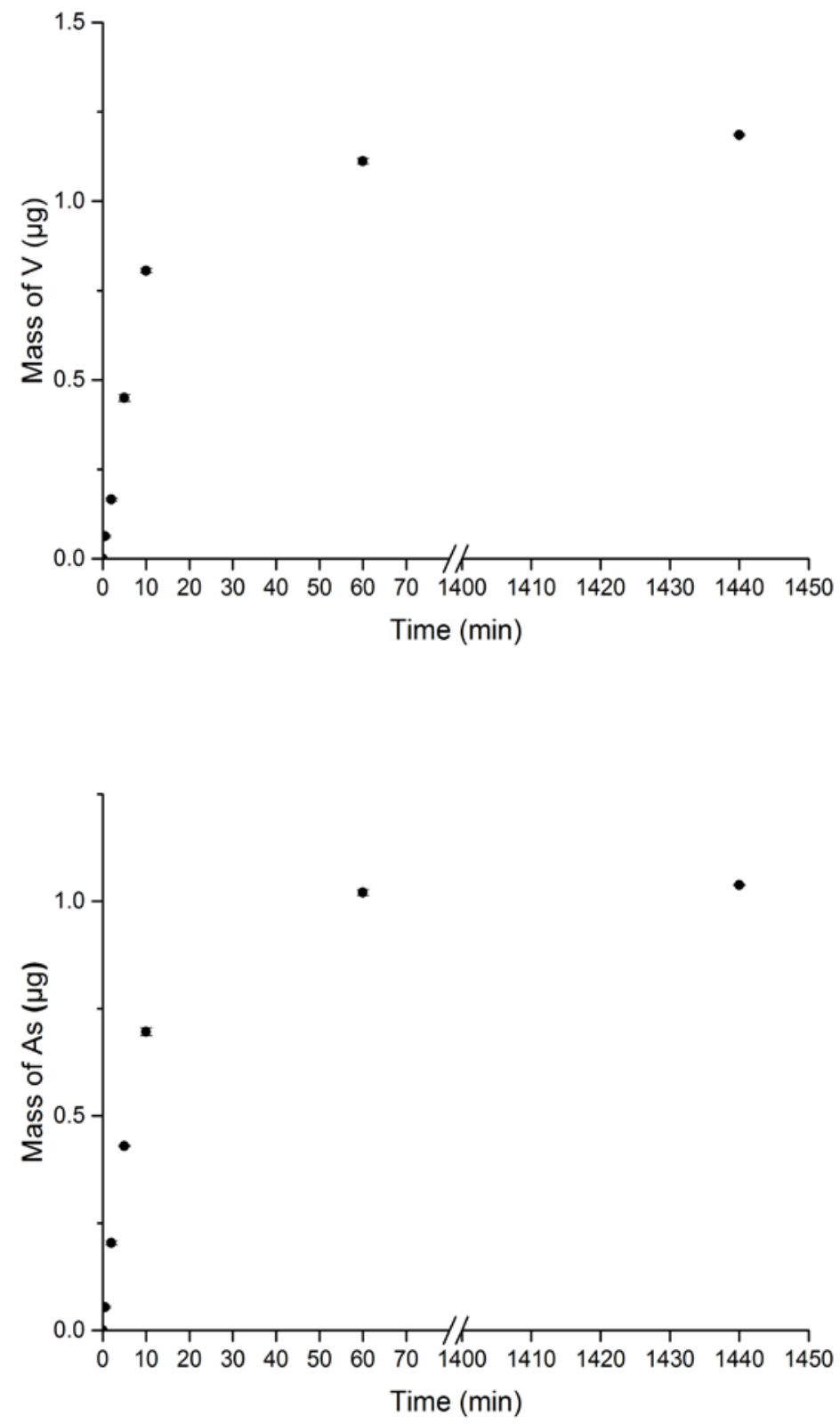

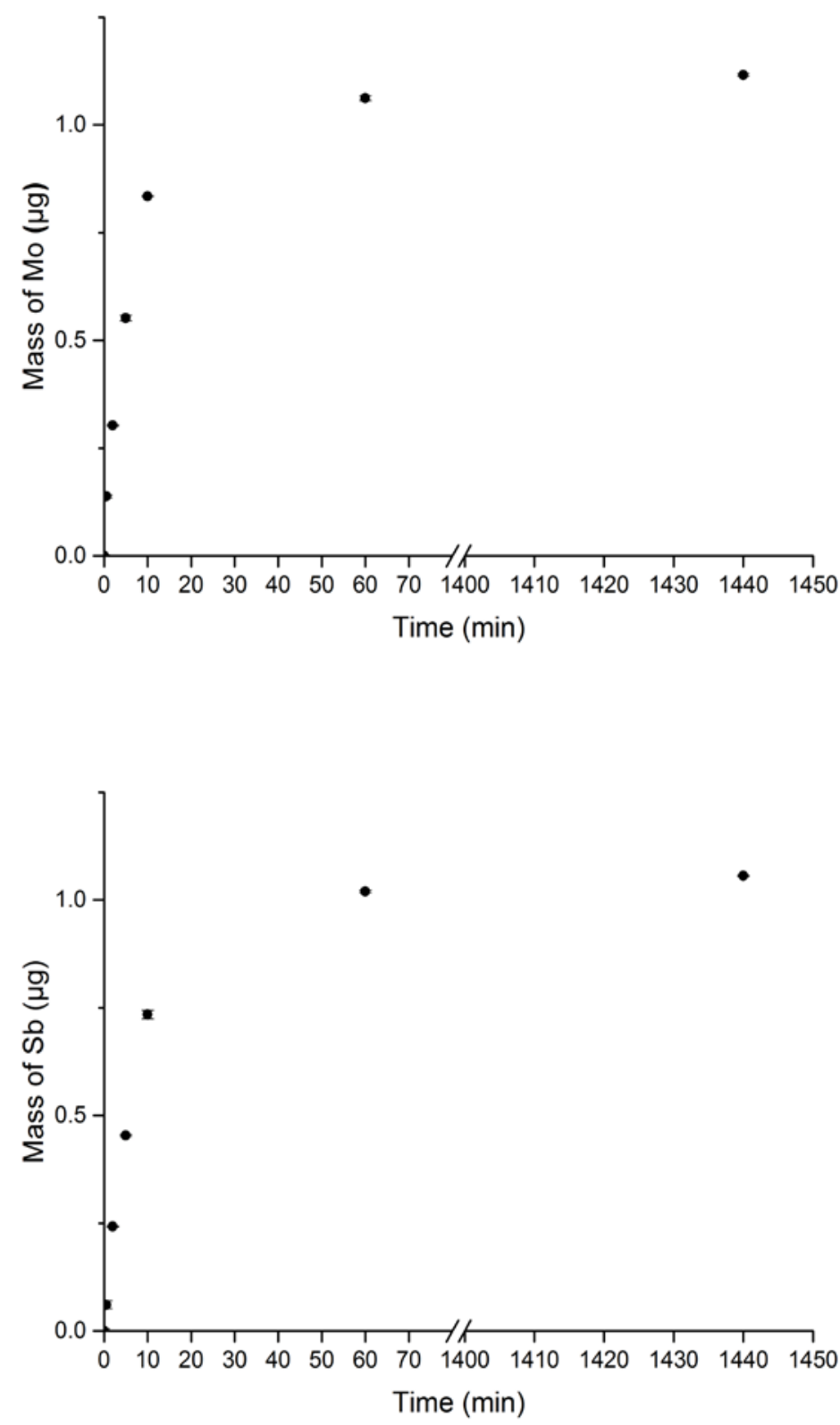

588 Fig. 1. Mass of $\mathrm{V}^{\mathrm{V}}, \mathrm{As}^{\mathrm{V}}, \mathrm{Sb}^{\mathrm{V}}$ or $\mathrm{Mo}^{\mathrm{VI}}$ accumulated by SF gels immersed in solutions 589 containing $100 \mu \mathrm{g} \mathrm{L}^{-1} \mathrm{~V}^{\mathrm{V}}, \mathrm{As}^{\mathrm{V}}, \mathrm{Sb}^{\mathrm{V}}$ and $\mathrm{Mo}^{\mathrm{VI}}$ for different immersion times. Error 590 bars are calculated from the standard deviation of replicates $(n=3)$.

591

592 


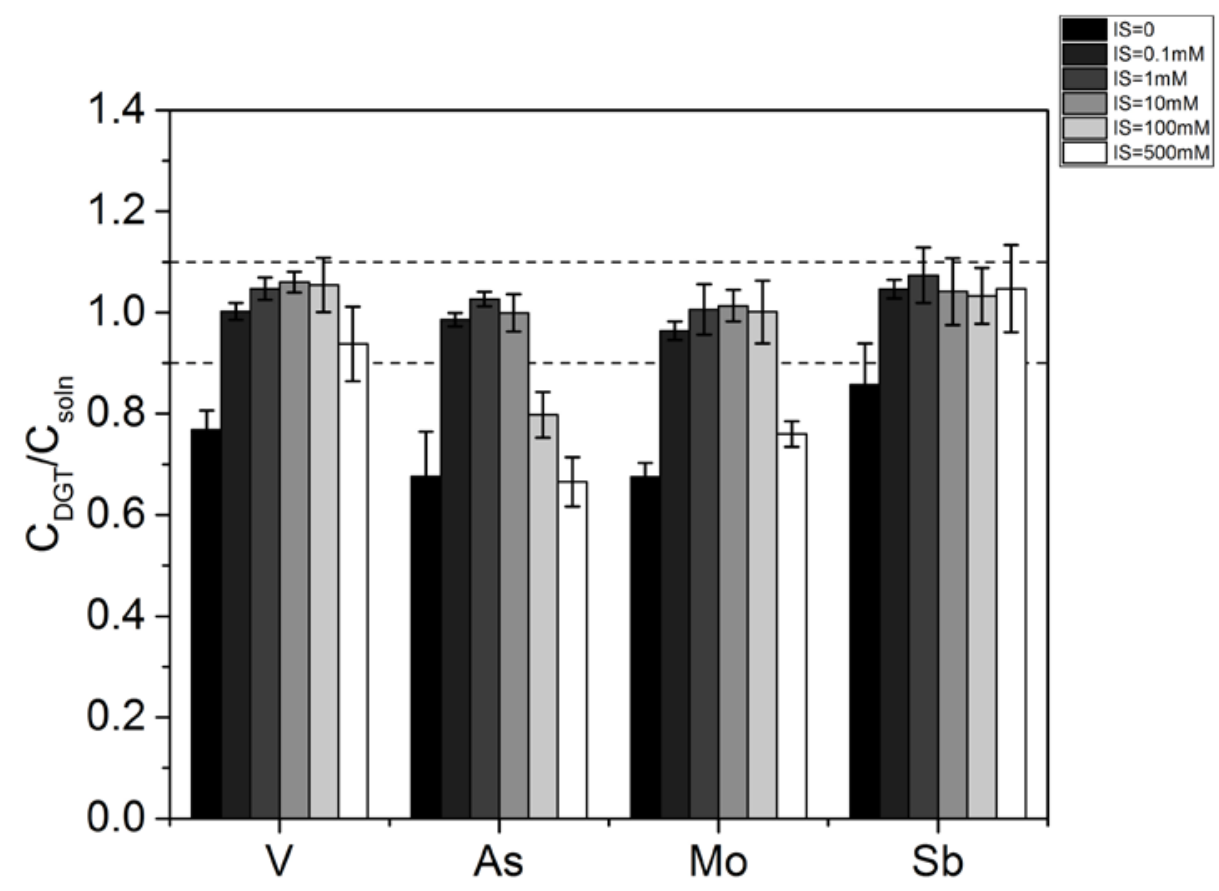

594

595 Fig. 2. Effect of concentrations of supporting electrolyte, $\mathrm{NaNO}_{3}$, on the ratio of

596 concentrations measured by SF-DGT, $C_{\mathrm{DGT}}$, to deployment solution concentrations of

$597 \mathrm{~V}^{\mathrm{V}}, \mathrm{As}^{\mathrm{V}}, \mathrm{Sb}^{\mathrm{V}}$ and $\mathrm{Mo}^{\mathrm{VI}}, C_{\text {soln. }}$. These measurements were performed in the $\mathrm{pH}$ of

598 5.85.Error bars represent the standard deviation of three replicates. The solid

599 horizontal line and dotted horizontal lines represent target values of 1.0 \pm 0.1 .

600

601 


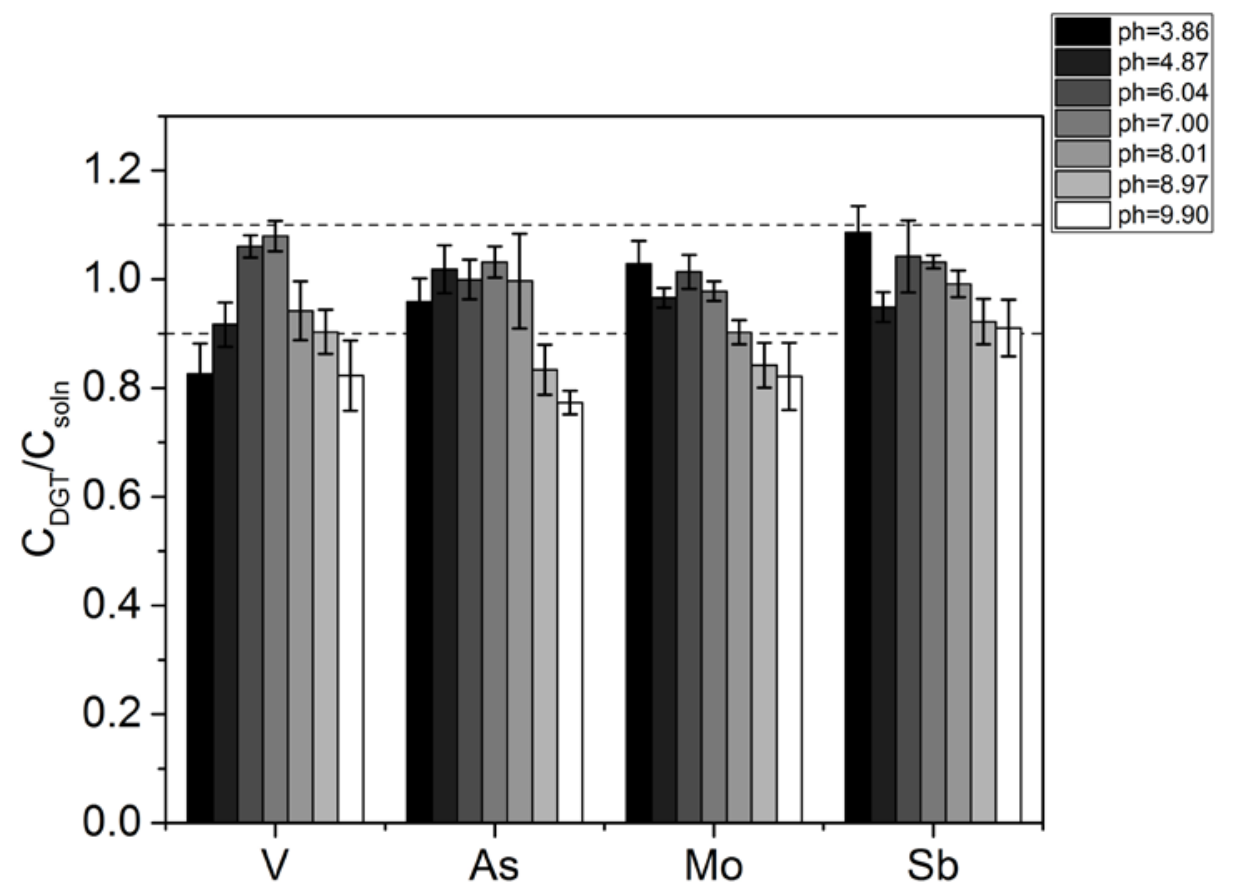

603

604 Fig. 3. Effect of $\mathrm{pH}$ on the ratio of concentrations of $\mathrm{V}^{\mathrm{V}}, \mathrm{As}^{\mathrm{V}}, \mathrm{Sb}^{\mathrm{V}}$ and $\mathrm{Mo}^{\mathrm{VI}}$

605 measured by SF-DGT, $C_{\text {DGT }}$, to deployment solution concentrations, $C_{\text {soln. }}$. These

606 measurements were performed in the presence of $10 \mathrm{mM} \mathrm{NaNO}_{3}$. Error bars represent

607 the standard deviation of three replicates. The dotted horizontal lines represent target

608 values of $1.0 \pm 0.1$.

609

610 


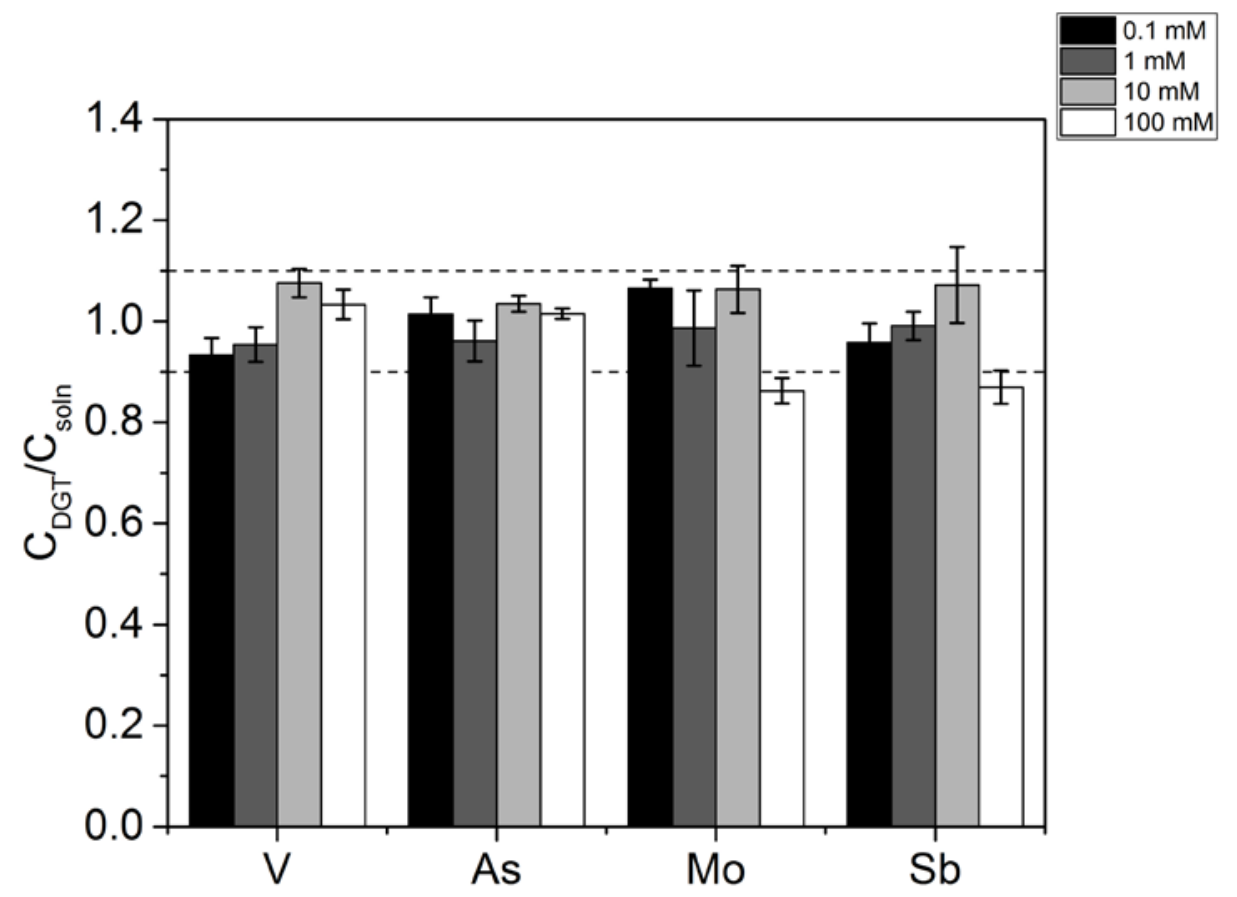

611

612 Fig. 4. Effect of competition with $\mathrm{SO}_{4}{ }^{2-}(0.1,1,10$ and $100 \mathrm{mM})$ on the ratio of 613 concentrations of $\mathrm{V}^{\mathrm{V}}, \mathrm{As}^{\mathrm{V}}, \mathrm{Sb}^{\mathrm{V}}$ and $\mathrm{Mo}^{\mathrm{VI}}$ measured by SF-DGT, C C ${ }_{\mathrm{DGT}}$, to deployment 614 solution concentrations, $C_{\text {soln }}$. These measurements were performed in the presence of $61510 \mathrm{mM} \mathrm{NaNO}$. Error bars represent the standard deviation of three replicates. The 616 dotted horizontal lines represent target values of $1.0 \pm 0.1$. 
618

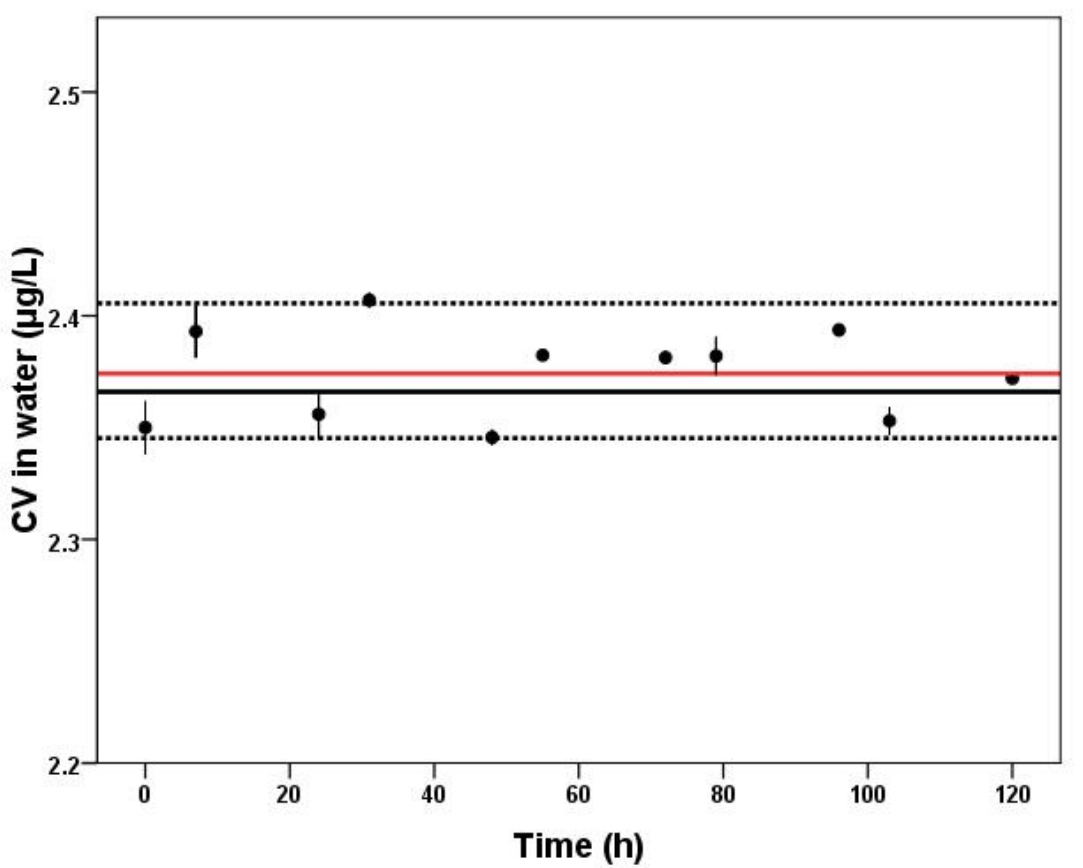

619

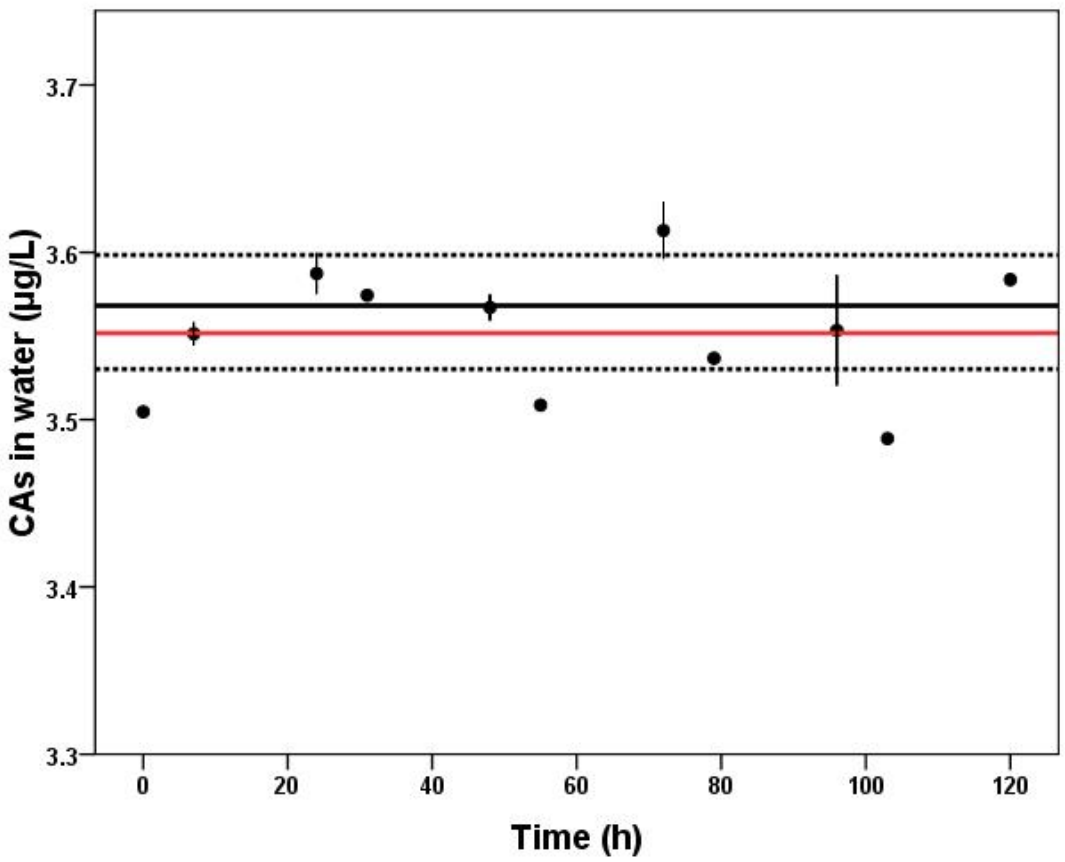

620 


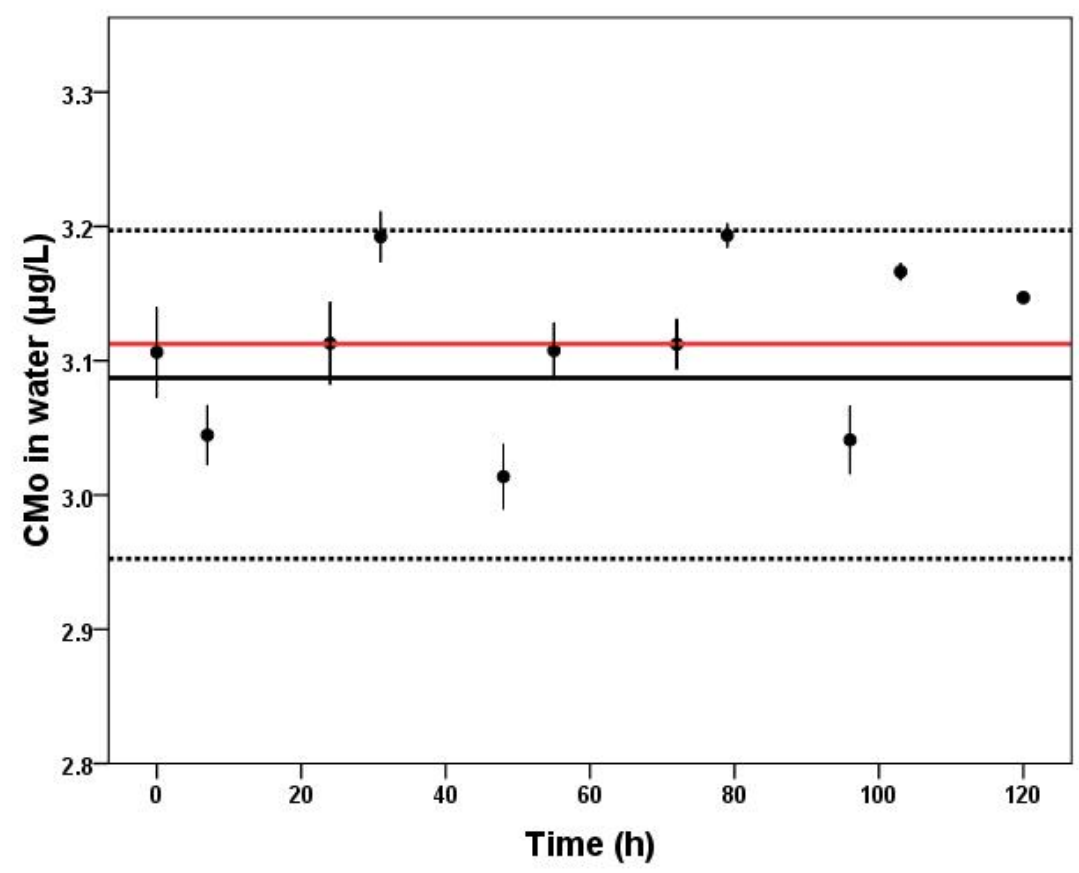

621

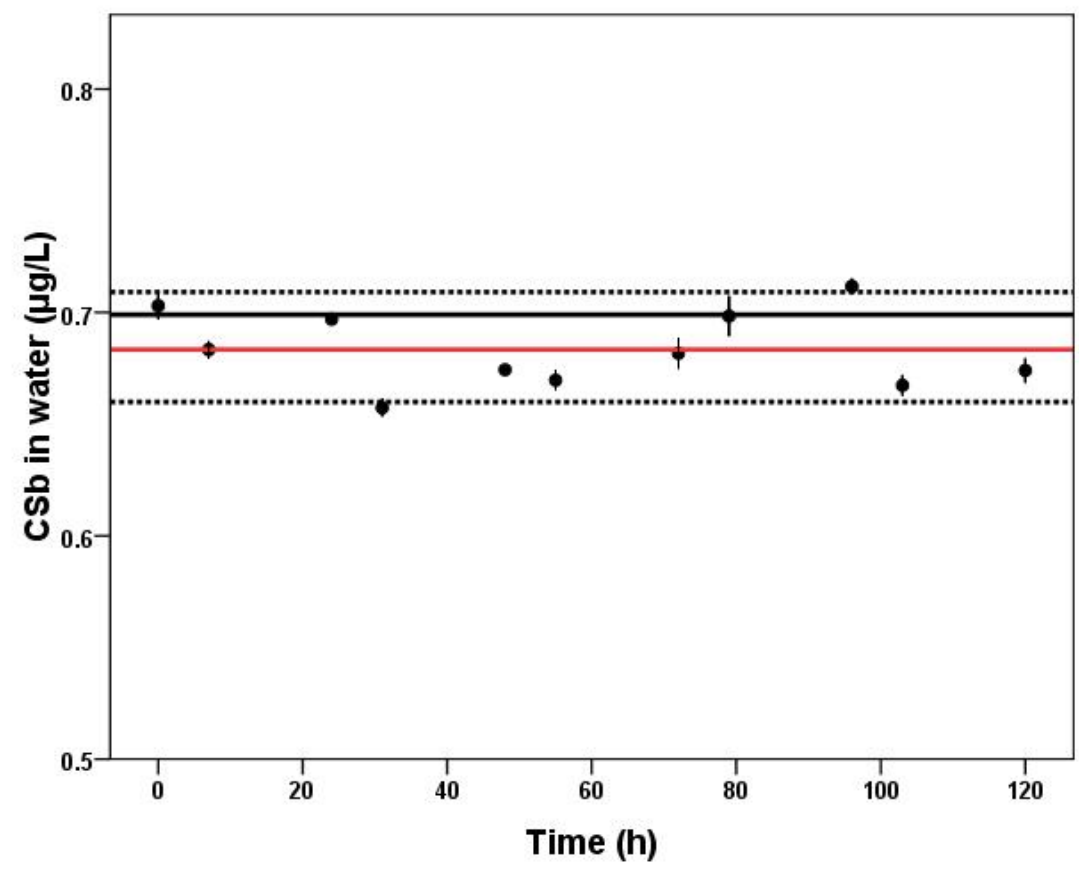

622

623 Fig. 5. Measurement of $\mathrm{V}^{\mathrm{V}}, \mathrm{As}^{\mathrm{V}}, \mathrm{Sb}^{\mathrm{V}}$ and $\mathrm{Mo}^{\mathrm{VI}}$ concentrations by two methods at 624 different sampling times in Jiuxiang River. The black points represent the 625 concentrations measured by active sampling method. The solid red line represents the 626 average concentration of $\mathrm{V}^{\mathrm{V}}, \mathrm{As}^{\mathrm{V}}, \mathrm{Sb}^{\mathrm{V}}$ and $\mathrm{Mo}^{\mathrm{VI}}$ from active sampling method during 627 the five days. The solid black line means the average concentration of $\mathrm{V}^{\mathrm{V}}, \mathrm{As}^{\mathrm{V}}, \mathrm{Sb}^{\mathrm{V}}$ 628 and $\mathrm{Mo}^{\mathrm{VI}}$ measured by SF-DGT and the upper and lower dotted black lines mean the 629 maximum and minimum DGT measured concentrations. 